\title{
MBC Ventures, Inc.: An Employee Stock Ownership Plan With A Union Partner
}

Richard C. Hoffman, Salisbury University, USA

M. O. Brown, Jr., Salisbury University, USA

Frank Shipper, Salisbury University, USA

\begin{abstract}
MBC Ventures, Inc. is a 161 year-old company that is going through both product and organizational transitions. It has left one of its traditional product lines, paint brushes, behind and has developed a new one, solar panels. The organization has gone from being part of a large diversified conglomerate to a small employee-owned company with two distinct product lines. The second product line, solar panels, has been added only recently. The organization has gone from being a product unit within a hierarchically-oriented, large diversified conglomerate to an independent, team-oriented, egalitarian organization. The conglomerate was a publically traded organization; whereas, MBC Ventures is employee owned. The transition to employee ownership would not have been possible without the cooperation and financial assistance of the United Steelworkers union. These transitions that have occurred since 1990 have not been without problems including two major recessions. Currently, the company is doing quite well. This case discusses how the firm has implemented employee ownership and participatory management, and its decision to diversify into a new growth product line. Some financial results are provided.
\end{abstract}

Keywords: Employee Stock Ownership Plan; Employee Ownership; United Steelworkers; ESOP; Governance

\section{INTRODUCTION}

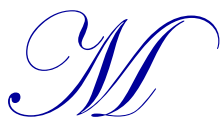

BC Ventures, Inc. (MBC), known as the Maryland Brush Company until a name change in 2011, is a 100 percent employee-owned United Steelworker Employee Stock Ownership Plan (ESOP) established in 1990. Throughout its recent history, the 161 year old business has steadily increased its stock value. However, the future is less certain today as the firm's traditional brush business has matured, and its recent efforts at diversification have yet to be realized. The firm has proven to be quite resilient over the years having averted closure after being sold by PPG Industries in 1990. In an unusual partnership, the United Steelworkers of America union helped the firm's new owner-managers convert to an ESOP as part of a reorganization. This effort saved jobs and the company. Since that time, the firm's employees have proven to be its most valuable asset and a key source of its competitive advantage.

\section{COMPANY BACKGROUND: THE GENESIS OF AN ESOP}

MBC Ventures, Inc. began operations in 1851 as a supplier of paint applicators and maintenance brushes to the agricultural, industrial, and consumer markets in Baltimore, Maryland. In 1904, Pittsburgh Plate Glass (later known as PPG) acquired MBC as part of a diversification process that also included the acquisition of Patton Paint Company in Milwaukee, Wisconsin. MBC produced paint applicators that were sold to PPG's end user accounts, as well as maintenance and power brushes to its own industrial accounts. PPG announced its intention to sell MBC in October, 1987. Several of PPG's competitors, as well as a group of MBC's management, expressed interest in purchasing the Baltimore operation. In addition, an official with the United Steelworkers of America, the union representing the Baltimore plant employees, decided to consider assisting a possible purchase of the operation by the employees. The union official then enlisted the services of an employee buyout specialist who conducted a study of the feasibility of an employee purchase of the operation. The consultant's conclusion was that the employee buyout was possible under the following conditions: (a) the union employees would have to make concessions in their 
compensation package, (b) the management employees would have to make a financial investment in the new operation, and (c) an interested commercial lender had to be secured. In addition, the specialist concluded that, not only could the employees buy the plant, but also it could be operated at a profit, and the loans used to finance the purchase could be repaid in about five years. Once this information was shared with the management of the Baltimore operations who were also interested in purchasing the plant, management joined forces with the workers and submitted an offer to PPG. As stated by one of the employees "What did we have to lose? We were going to be out of a job anyway", since the other potential buyers intended to move the operations out-of-state. In the end, only two bids were submitted for the purchase of the operation, and PPG accepted the offer from the employees. An additional part of the deal which helped secure financing for the employees was a long-term agreement by PPG to purchase brushes from MBC.

The issues that now faced MBC employees and management were how to structure the deal and how to raise the nearly $\$ 5,000,000$ necessary to fund the purchase. There are a number of methods by which an employee buyout of a company can be structured. These include, but are not limited to: (1) An Employee Stock Ownership Plan (a trust fund which holds the stock that is allocated to the employees); (2) The Employee Cooperative or (3) Direct Stock Ownership of a regular corporation in which most or all employees directly own stock and few or no outsiders own stock. Moreover, federal tax laws permit substantial financial benefits to employee buyouts, including but not limited to, possibly lower interest rates on borrowed funds and deductions for the payment of both principal and interest on the loans. The eventual deal accepted by the firm was the first option, whereby, a trust fund is established which holds the stock that is to be allocated to the employees individually. The money necessary to fund the purchase of the plant came from a variety of sources. First, union employees agreed to concessions in their compensation package. Specifically, the average hourly rate was reduced from $\$ 10.00$ an hour to $\$ 9.40$ an hour; a six percent $(6 \%)$ decrease in hourly pay. In addition, there were reductions made to vacation time and changes made to the employee health plans. Second, funds were borrowed from both private and public sources. Specifically, the First National Bank of Maryland provided \$3,035,000; the state of Maryland offered $\$ 1,500,000$, the city of Baltimore issued $\$ 110,000$ in debt financing, and the facility's management group provided $\$ 210,000$. PPG accepted the employee offer, and the buyout was completed on February 1, 1990. Under the agreement, the stock of the company was placed in a trust fund. As loans were re-paid, the stock was distributed to the employee-owners. The agreement also called for the management group to sell back their stock in the company after 5 years. During that five year period, there was no increase in the value of the company stock so each investing employee received back the same dollars they originally invested in the firm. At the time the company was formed in 1990, three loans were established between the company and the primary commercial lender. Three more loans, mirroring the mentioned commercial loans, were established between the company and the ESOP because no financial institution was willing to lend directly to the ESOP. The last of the commercial loans was satisfied in 2005. In 2010, MBC reorganized its debt. The State of Maryland loan was replaced with a commercial loan having more favorable terms, and two new loans were established. The first loan helped finance its initial 2009 investment in a new product line, and the second loan helped finance the 2010 acquisition of brush manufacturing equipment from Germany.

\section{BUSINESS ENVIRONMENT AND STRATEGY}

Maryland Brush Company, the original company created as an ESOP in 1990, was reestablished as a division of the newly named MBC Ventures, Inc. in 2011 to address brush product customers. Maryland Brush began as a producer of brooms and brushes for industrial clients and consumers. Today, the Maryland Brush division focuses on brushes intended for industrial use. The brushes are made of either metal or synthetic filaments for use on hand held or automated power driven machines to smooth, sand, or grind materials being processed by end user customers. Maryland Brush division brushes are sold primarily to the metalwork, millwork, tire retread, pipeline, and welding industries in North America and internationally.

MBC Ventures is a member of the American Brush Manufacturers Association that has represented manufacturers of brooms, brushes, mops and rollers (SIC 3991) since 1917. The association has established standards for the industry, provided opportunities for members to learn about new products and processes, served as the industry's representative to government as well as provided a network for members. 
Currently, the brush industry is composed of about 80 brush manufacturers and another 80 supplier firms. It is a $\$ 200$ million a year industry. MBC ranks about $5^{\text {th }}$ in the industry with less than $10 \%$ of the market. Unlike the other major competitors who carry other product lines such as abrasives and safety supplies, MBC focuses exclusively on brushes for industrial use.

The U.S. brush manufacturing industry today is contracting in part because many brooms, brushes and mops that were made by hand and sold to mass markets in the US are now produced overseas in lower-wage countries. Furthermore, on the industrial side, many old line industrial firms have been consolidated and even closed their doors as the US economy shifted from a manufacturing to a service economy. Today's industrial brush market is truly a niche market.

\section{Strategy for Changing Times}

Faced with competing in a slow growth and even declining industry, MBC's management has taken a two pronged approach to improve its firm's performance. In the traditional brush sector, it has consolidated its position and focused on the niches where it has a competitive advantage. In 2001 the firm discontinued its line of high quality, professional paint brushes that were mostly made by hand and sold to the mass market because it could no longer compete on price. The firm focused on the manufacture of engineered power brushes for industrial use, and the resale of commodity paint, maintenance and power brushes. As Steve Mullan, the firm's President and CEO noted, "...we are investing in and developing niches where we can provide technical expertise for companies. In these areas we have a competitive advantage. We hope to leverage our niche brush market revenue as we seek to diversify the corporation, enabling us to grow". These niche market opportunities have taken the form of providing engineered solutions for its clients' production processes. By understanding the processes better, MBC can produce brush products that best suit the application for which it is to be used.

\section{Diversification}

Recognizing that its traditional brush market as a whole was stagnating or in decline, the firm has devoted considerable management time and effort in protecting its future revenue base by seeking a new avenue for diversifying the firm. In investigating new diversification alternatives, Steve noted the following as important considerations. First, "We think the brush business will not grow and likely will recede over the years". In selecting the right opportunity an important consideration was "... to determine what we are good at and identify our strengths and weaknesses. We are good at manufacturing things made of metal.” Additionally, “... we wish to take a new product down different distribution channels from our brush business to increase our opportunity for success in our brush and our newly developed diversification endeavor". This would enable the firm to manage the product independently at some point in the future if it were deemed appropriate. In a process that took roughly five years, the firm narrowed its diversification product choices to two areas; either the alternative energy or environmental industries. With the help of consultants, MBC's management finally settled on an alternative energy technology. After the investigation and review of alternative energy opportunities, in 2009 the company selected to align itself with and invest in a Denver firm with its product known as Photensity.

In 2010 MBC purchased all intellectual property rights to the Photensity product and renamed it SkyLouver ${ }^{\mathrm{TM}}$. The SkyLouver system is a unique rooftop solar energy system that harvests and distributes high quality daylight for use in the space beneath the installation, as well as large amounts of thermal energy. The thermal energy can be stored in insulated water tanks until needed to heat or cool room space or to satisfy the process heating or cooling needs of the facility. SkyLouver modules have articulating louvers that concentrate and direct natural daylight into a building, and convert the sun's energy into thermal energy through a heat transfer fluid. Compared to a photovoltaic solar panel that generates electricity, the SkyLouver technology is simpler to construct, is more efficient, and as a result, it can be competitively priced. Additionally, all harvested energy is used by the facility, thus, eliminating the transfer of energy to the grid where transmission losses occur. Buildings having a flat roof profile are candidates for this technology. According to Robert, the firm's manufacturing engineer, the product has a payback that is years faster than that of a traditional photovoltaic solar panel; this is expected to be appealing to a wide variety of customers. 
Thus, MBC's strategy going into 2011 was that of a niche manufacturer of engineered brushes that was diversifying into the manufacture of SkyLouver solar modules and the accompanying storage and distribution systems. The first successful SkyLouver installation was completed December 2011 on the roof of Building 9 at MBC's Baltimore facility. The 50 module system provides natural daylight to the brush making operation below. Approximately $90 \%$ of the day shift can be run with natural daylight provided by SkyLouver rather than from expensive artificial electric lighting. The thermal energy is collected on the second floor of Building 8 and heats and cools the SkyLouver assembly area. MBC received a \$770,000 United States Department of Energy CEEDI grant through the Maryland Energy Administration to help with expenses of setting up the SkyLouver manufacturing line and installing the product at its facility.

\section{MANAGEMENT AND GOVERNANCE STRUCTURE}

To say that MBC possesses a flat organization structure is truly an understatement. The firm's top management team consists of Steve, and Tim Hartman, Vice President. They are ably assisted in the task of managing the firm by a small office staff and a team structure that cuts across the entire organization. Management reports to and is greatly supported by an active board of directors (see Exhibit I). Two things that are key to understanding the firm's governance are the structure and roles of teams and that of the board of directors.

\begin{tabular}{|c|c|c|}
\hline \multicolumn{3}{|c|}{ Exhibit I MBC Ventures, Inc. Governance Structure } \\
\hline \multicolumn{3}{|c|}{$\begin{array}{l}\text { Board of Directors } \\
\end{array}$} \\
\hline \multicolumn{3}{|c|}{$\begin{array}{l}\text { Mary Landry, Chair } 20 \text { yrs. on board, external director. Retired college librarian } \\
\text { BA College of New Rochelle, MLS Columbia University } \\
\text { MA Management Notre Dame of Maryland University } \\
\text { Board seat nominated by USWA District Director \& affirmed by management }\end{array}$} \\
\hline Steve Mullan, President/CEO, 24 yrs. on board & \multicolumn{2}{|c|}{ Tim Hartman, V.P. and Corporate Secretary } \\
\hline $\begin{array}{l}\text { Richard Benton, Die setter and Union President } \\
41 \text { yrs with firm. Union President automatic } \\
\text { appointment to board }\end{array}$ & \multicolumn{2}{|c|}{$\begin{array}{l}\text { Gwen, Team Leader \& Shop Steward } \\
40 \text { years of service to the firm. } \\
\text { Elected by local union }\end{array}$} \\
\hline $\begin{array}{l}\text { Don Forcino, Retired trainer and union organizer -external } \\
\text { director appointed by USWA District Director. }\end{array}$ & \multicolumn{2}{|c|}{$\begin{array}{c}\text { Don Lamb-Minor, retired consultant, } \\
\text { external director appointed by management }\end{array}$} \\
\hline Top Management & \multicolumn{2}{|c|}{6 Teams } \\
\hline $\begin{array}{l}\text { Steve Mullan, President/CEO, } 29 \text { yrs. } \\
\text { BSME Villanova University, MEME Carnegie-Mellon } \\
\text { University, MBA Loyola of MD, PE, CMfgE, } \\
\text { automatic appointment to the Board. }\end{array}$ & $\begin{array}{l}\text { Customer Support Team } \\
\text { Customer Sales Team } \\
\text { SkyLouver Team }\end{array}$ & $\begin{array}{l}\text { Brush Make Team } \\
\text { Brush Finish Team } \\
\text { Brush Support Team }\end{array}$ \\
\hline $\begin{array}{c}\text { Tim Hartman, Vice President, } 41 \text { yrs. } \\
\text { BS in Business Towson University, Elected by salary }\end{array}$ & & \\
\hline
\end{tabular}

\section{Team Structure}

Perhaps the second most revolutionary event in MBC's modern development after the ESOP was the installation of a team structure throughout the firm. In the early nineties, with the change in management, the firm looked for a way to improve the organization, reduce expenses, and better utilize its biggest asset, its employees. "We decided to invest in teams, team development. We brought in consultants that provided extensive team training. All employees received training in group dynamics, problem solving, and various other team development areas. Classes in basic math and English training were provided to all individuals requesting assistance" according to Steve. In the beginning, many of the employees were not convinced of the team concept. As one team leader noted, "A lot of the employees fought it. ... a lot of them had trouble taking direction from a peer worker." Today employees at all levels seemed to have embraced the team concept. As one team leader remarked, with the team concept, “... you could be more involved. In the past, you went to a certain [work] station and stayed there. And now it's you go to this team, and you learn these different aspects of different jobs, and it's actually more interesting. You move around. You get to do more."

There are 6 teams in MBC's structure. Three of the teams are in the manufacturing area, and they are responsible for scheduling the work as well as keeping track of employee absences. The Brush Make Team, Brush Finish Team, and Brush Support Team mentioned in Exhibit I are comprised of unionized employees. The Brush 
Make Team headed by Colleen, a Cut and Bunch operator responsible for preparing all wire fill material for production use, is responsible for the initial steps of manufacturing brushes on traditional machines. The Brush Finish Team headed by Gwen, a Manual Section Machine operator, is responsible for the completion steps on another set of manufacturing machines. The Brush Support Team is the maintenance team headed by Harold, a machinist; his team members include a die setter, Richard (also president of local union and member of the MBC board), and a maintenance mechanic. The office team includes the president and vice president as well as the three other staff members who oversee the daily office operations. This team is headed by Ruth the staff member in charge of Purchasing and Human Resources. As far as Steve's role on the team, it was noted that, "... he is sort of an independent observer of the team. But, yes, he sits in on our meetings and participates." The sales team is headed by Tim and is comprised of Baltimore-based and outside sales persons.

There are overlapping memberships on some teams. For example, a wage employee is on one of the manufacturing teams, but, because he is also involved with shipping and receiving, he serves as part of the office team when working in that capacity. Having employees participate in more than one team reflects both lean staffing throughout the company and the need for extensive interaction among employees in a small organization. Most team members perform multiple roles over the course of a day or week. A major reason for this is that, "A lot of people don't have 40 hours of actual work on their job, “... so I might do a little die setting and, if they need me, I might go pack brushes. So you do other things" (Richard, die setter). Having multiple job roles is not without its problems as employees often felt that others were taking over their jobs and others felt that some employees tried to avoid more difficult work. In principle job flexibility worked in the following manner: "We all hold a certain title. But if you're finished in that area, and you go do somebody else's job, as long as that person is doing that job too, it's okay," (Gwen, Team Leader). As far as people gravitating to easier jobs, Gwen stated that, "If I feel like somebody is treading on my toes, I just say something, or they'll do the same thing. And you just try and work it out."

Overall, MBC's employees are positive about the management style under Steve and the team concept from autonomy to the open communications it seems to afford the employees. The manufacturing engineer (Robert) expressed that "...One of the benefits of the position that I'm in, my time is not necessarily regulated as I have tasks and things that need to be done. But I'm able to work at a self-pace with those items." Moreover, "The communication from all levels is open."

\section{Board of Directors-Structure}

MBC's board meets every month to assist in the governance of the firm given its lean management structure and high employee involvement. Seven people sit on the board: three appointed by the union, three appointed by management and one neutral seat, appointed by the district union officer and approved by the company president. At this time the union members include the local union president, who is also a die maker for MBC, the leader of the Brush Finish Team elected by the union employees, and a retired union organizer appointed by the district director of the union. Management appointees are the company's president and vice president, and one external director approved by the president. The seventh seat is nominated by the local steelworkers union and approved by MBC management, (Exhibit I). Mary Landry, the current board chair has served in that capacity for 19 years. Her husband previously sat on the board. She replaced him upon his untimely death and was reelected to the position later once his term had expired. Directors who are not employees are paid a fee and cannot own shares of company stock unless those shares were earned as an employee. All board seats are subject to reelection at the company's annual stockholders meeting.

\section{Board Processes}

The board meets monthly to assist the management team in making strategic and financial decisions. A day or so after each of these board meetings, the union and employee representatives on the board hold a meeting with the union employees to disseminate information about the meeting to keep all informed.

Some key contributions of the board to the firm's management included its involvement in making the transition to an ESOP successful. In the first year, the management team at that time did not understand the power of an ESOP in harnessing the motivation of employee owners. The board took action in 1991, changing the management team to one more willing to work cooperatively with the employees. 
More recently, the board played an important role in the firm's diversification decision. The process was initiated by Steve, who only too clearly realized that the brush business would not provide the growth the company sought. Steve had a challenge in convincing the board of the need to diversify. At some point there appeared to be a trust issue between Steve and the internal members of the board, "Why does he want to do that [diversify]?" Steve reasoned, "I don't want the board to rubber stamp anything. I want them to evaluate and understand where we are and what we face in the future. I want them to be convinced that diversification is the right thing to do." This discussion was protracted for almost three years. Once convinced of the need to diversify, the board turned to one of its members who had a marketing consulting practice and contracted his firm to help MBC identify diversification opportunities that matched the company's cultural, economic, and technical resources, and to come up with at least six ideas. The Photensity solar energy opportunity was about fifth on the list. The board sought input from employees as well. As one team leader noted, "...we know the brush business is not going to go on forever... we wanted to grow. Do something, a new venture." Upon the ultimate selection of SkyLouver as its new diversified product line, Steve reflected, that, "We thought that this was a good fit given our assets, our people, our experience and our facility ... all our strengths and capabilities." The total amount of funds devoted to investigating the solar opportunity was large, but a fraction of the firm's overall assets so it seemed to be a reasonable risk for the company.

Formally, the board approves officers of the company. The board also provides a list of nominees to function as board members for the following year, and this slate is presented at the annual meeting of the shareholders for their vote, along with approval of the auditing firm and any other business brought before the group. Any financial decision whose value is roughly half of the firm's assets is very significant and would be brought up for a shareholder vote. If the board decided to sell the company, this would have to be approved by a vote of all ESOP Plan participants.

When asked how she felt about being a board member, Gwen, stated, "Very informational with regard to a lot of stuff that I would have never thought about before ... how the company is run and who is controlling what. And it's very interesting. ...until you hear that stuff, you don't realize what's actually involved in running this place."

\section{OTHER FORMS OF EMPLOYEE INVOLVEMENT}

In addition to self-managed teams, $\mathrm{MBC}$ uses other specific programs to encourage employee involvement in the firm on a continuous basis. The two most prominent of these are the ESOP and gainsharing program that provide employees with a share in both the ownership and profits of the firm.

\section{Employee Stock Ownership Plan (ESOP)}

Perhaps the most attractive benefit offered by MBC to its employees is the ESOP. To become fully vested in the ESOP, an employee must have worked at MBC for three years. The stock in MBC is distributed to MBC employees based on the number of hours actually worked in a year with a cap of 40 hours per week. Therefore, every employee, including management, must complete a daily timesheet containing the number of hours worked. Also, if an employee is sick and misses work, that employee will not be credited for hours worked and will not earn as much stock. As Steve stated "it makes sense to count only those employees who are at work because those are the ones who have an opportunity to positively contribute to the organization". Because employees may work different amounts of time throughout the year, it is highly unlikely that any two employees would own the same number of shares of stock.

There are two types of distributions possible to employees under the ESOP. The first is called the retirement/separated employee distribution program. As explained by Steve, when someone separates, the year after their separation, they are eligible for distribution. The distribution is made over five years with the employee receiving $20 \%$ of their shares in each of those years. Those shares can be put back to the company at the prevailing share value for that plan year. The separated employee has the option of when to begin the distribution. But, once the separated employee begins the distribution, it will continue for five years at which time the distribution concludes. The separated employee, in deciding when to begin the distribution, is taking a risk as to whether the value of the shares of stock will increase or decrease. 
The second type of distribution is the diversification distribution. To qualify for this type of distribution, the employee must be 55 years of age or older and have ten (10) years of service. An eligible employee may request a diversification distribution the year after the latter of these two events occurs. This method of distribution lowers an employee's risk in that they can reduce their financial investment in MBC and instead develop or add to an independent IRA. This distribution process occurs over five years, allowing an eligible employee to diversify up to 25 percent of their previously undiversified shares each year. During the sixth year of eligibility, an employee may diversify an additional $25 \%$ of the number of shares they earned since beginning employment for a total of 50\% of all shares. The employee may roll over the funds into an Individual Retirement account (IRA) or put the cash in pocket, accounting for applicable state and federal taxes and penalties.

The ESOP represents an integral part of the compensation package at MBC. As stated by Steve, "The annual value of the shares has increased over recent years, and it provides employees with a greater sense of involvement in the company since the shares represent ownership of the business." As explained by Richard, "....more so than the average person...you're really involved in things. You're involved in some of the decisionmaking on the floor where, before, with the supervisor, you were just told what to do without input."

\section{Gainsharing}

Another way in which MBC seeks to harness and increase employees' involvement in the company and positive contributions to performance is through Gainsharing. Gainshare programs are generally designed to support team work and to reward employees when they meet pre-determined standards. MBC managers and employees developed a gainshare matrix or model about 15 years ago after visiting a firm with a similar program.

A machine operator summed up MBC's program as follows:

"You have to make a quota each hour, yes. That's how we get our... gainsharing. It goes by performance. It's a lot of elements. Its performance, its accidents, things like that, all come into play. And if you go below the standard, you don't get gainsharing."

MBC's Gainshare model tracks and measures four broad performance areas and uses one or two measures for each area (weighted differently) that are tracked on a monthly basis using the matrix (Exhibit II):

1. Productivity: measures performance to standard (35\% of the total) of direct labor activity and indirect labor (10\% of the total)

2. Quality: measures material consumed to standard (10\% of the total) and customer credit memos -customer complaints or returns (10\% of the total)

3. Safety: safety days-lost time due to accidents (5\% of the total)

4. Financial: operating expense ratio - administration and selling costs versus manufacturing accomplishment (10\% of the total) and operating income (20\% of the total) 


\section{Maryland Brush Gainshare Matrix}

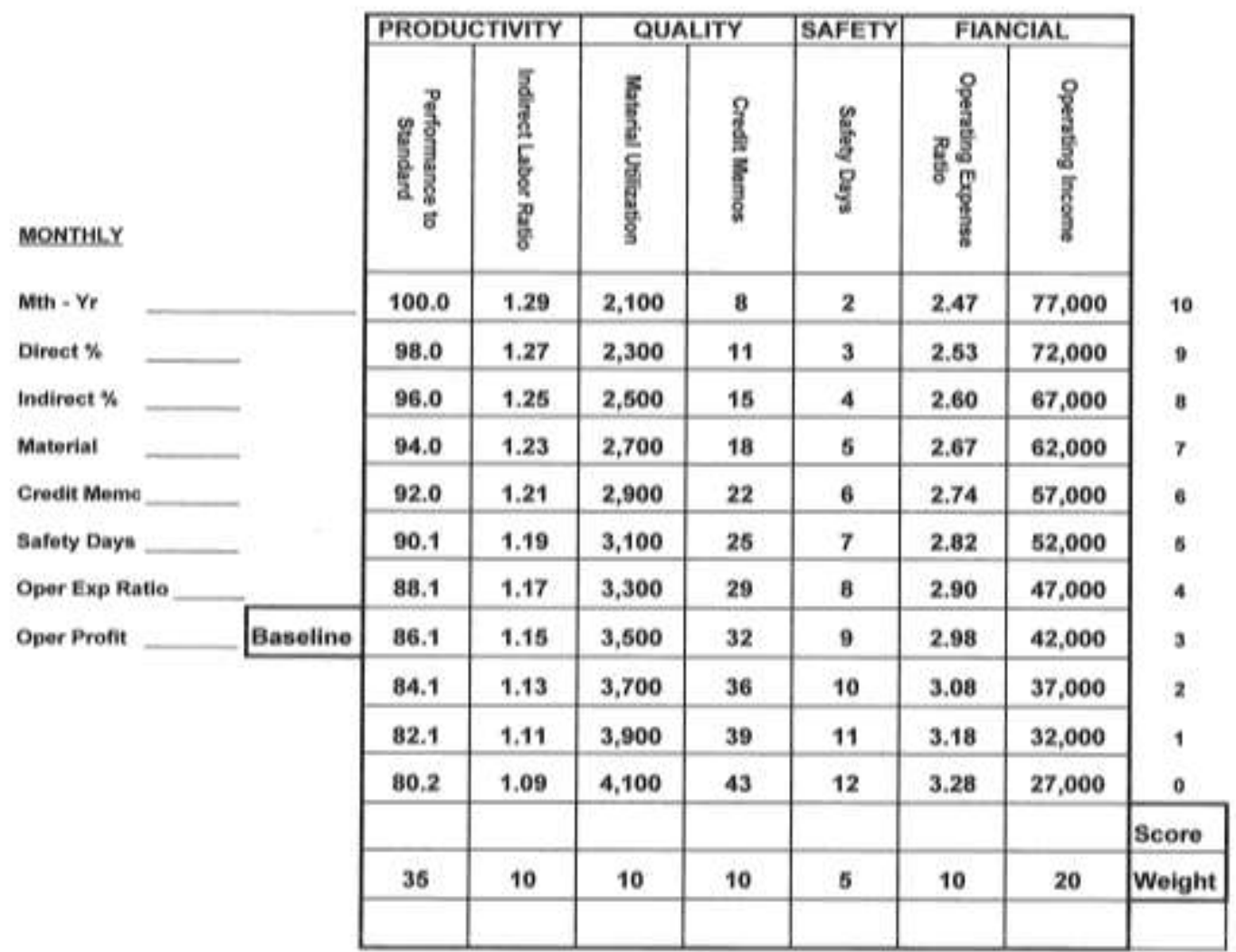

GUARTERLY

MONTH POINTS

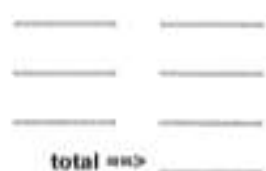

PAYOUT

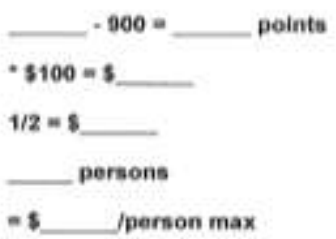

Exhibit II MBC Gainsharing Matrix

The firm used a number of years of historical data in developing the standard or the baseline for each of the seven (7) elements of the matrix. Currently, the baseline reveals that performance to standard is 86.1 , a goal achieved year after year. Likewise, the indirect labor ratio is fairly consistent at $115 \%$ or a ratio of 1.15 and so on across the baseline row on Exhibit II. Consistent achievement above the standard may result in a quarterly payout to the employees. Consistent achievement below the standard would result in no payout.

The matrix is completed each month and distributed to all employees for performance feedback. At the end of the quarter, a potential payout is calculated with the first 900 points (equal to three baseline months) subtracted from the total points. Employees are rewarded only for exceeding the 900 point overall baseline standard. Once the total payout is calculated, half is retained by the company to help support the program. The other half is divided by the total number of employees (hourly and wage) on the payroll. A person's actual payout may be reduced due to absences (illnesses or unexcused reasons). Normal paid vacations count towards the payout. In recent years, the annual payout has been as high as $10 \%$ of an hourly worker's income. See Appendix B for a complete example. 
MBC employees recognize the impact that the gainshare plan has on motivation and effort. In speaking about the monthly feedback, the tool and die maker noted that,

"It's got the gainshare matrix. You can follow that to determine how well you are doing, [and] if you need to pick it up a little bit." ... "So if you do well, you get extra money in your pocket quarterly through gainshare."

"It's nice. I work hard to get [gainshare] and it's rewarding. We do good work. The brushes we put out are quality brushes, and there's pride in our work." (Machine operator)

The Chair of MBC's Board summed up the program and its impact by remarking,

“...Our employee owners are doing like $111 \%$ productivity because ..., if the whole plant does well in gainshare,... they get a fair chunk of change if that gainshare averages out."

\section{BUSINESS OPERATIONS}

\section{Manufacturing - Brushes}

The order cycle for the company's brush products was described as follows:

"An order will come in. We have to determine if we have the materials to make or buy the product to satisfy the customer. If not, we create and manage all the work orders and the workflow. When it comes back, we get it into the system, we get the pick list out on the floor. And we bill the customer. We then receive the revenue, and we account for the revenue."

MBC's manufacturing operations are all located in a single plant in Baltimore. As a matter of fact, current production facilities took up only a quarter of the space available in the facility. In the past, the company had attempted unsuccessfully to lease some of the space. Given its entry into the alternative energy market with its SkyLouver product, the company has ample space to manufacture its new product line in the existing facility. Most of the brushes are made on machines that are operated by one person. The basic steps consist of cutting and sometimes twisting the filaments, which are then pressed between two metal stampings or plates to form the brush. Brushes vary in size by diameter, filament type, construction and thickness. Different types of brushes can be made on different machines. Each machine can make multiple sizes of brushes, and the operators are responsible for their own changeovers when they start producing a different size brush for a customer. Both the wire and metal stampings are sourced from various suppliers some of whom have done business with MBC for decades. Most of today's brushes are engineered to customers' specs. As one operator and team leader stated, “....the most important thing is the customer. To make sure we get the work out in a timely fashion is what keeps us in business."

Operators had a targeted hourly quota; achieving or exceeding the quota provided points toward gainsharing numbers calculated each month. A couple of years ago MBC purchased a large $\$ 350,000$ brush making machine from Germany to produce strip brushes. The machine operator who was to operate the machine and the company president traveled to Germany for one week to be trained on the use and care for the machine. This type of team work is an example of putting employee ownership to work.

MBC recycles cut wire and scrap metal that results from the manufacturing process. Bins are placed conveniently near the machines in the manufacturing area for that purpose. Employees are careful to separate metals. For example, brass wire goes in a bin separately from carbon steel or stainless steel. Paper and cardboard recycling is also practiced. As the manufacturing engineer remarked, "... everything is recycled here if it can be."

Team leaders and management also keep a close eye on safety measures making sure all who work in the production area have their safety glasses on for example. As one machine operator put it, “....there are so many areas for accidents." 
Many of the production employees develop their skills on the job, although some have come from manufacturing backgrounds. For example, Joe had been a forklift operator prior to coming to MBC. He started working with basic equipment and gradually moved up to operating the brush making machines. Gwen started by making paint brushes by hand. When that operation was shut down, she moved to engineered brushes and learned how to run the machines on the job. She can now operate six different machines. Margie, a section machine operator, worked with Styrofoam products at other firms, as she stated, "That was light work. This is kind of physical. I came from that to this. ...It was a big change. I had a lot to learn ... it took me awhile, but once you get it, you got it." More formal and external training occurs when new safety procedures or products are implemented, or when new machinery is acquired. Other than that the teamwork spirit seems to pervade how employees acquire new skills at the work place. Ruth, the Customer Service Team leader describes training at MBC as follows:

"It becomes a team function, and everybody participates. ... In the facility, we're always doing safety training, forklift operation, elevator things. There are union meetings on a regular basis that touch on safety. There's a lot of cross training of job functions that's done by the teams."

\section{Manufacturing - Solar Panels}

In January, 2011 MBC hired Robert as the manufacturing engineer for the new SkyLouver solar project. Robert was formerly a tool and die maker for a supplier of stampings for MBC's brushes, so he was very familiar with the company and its products. He was attracted to the position for two reasons. First, the fact that the company was growing by diversifying, "...bringing on the solar business which really excited [me] ... as far as making things." Secondly, "It's an ESOP company, so that you have a stake in the profitability and the future ..." Robert's responsibility is to create the manufacturing processes within the facility, and to lead the fabrication of the production solar units. In learning about the new technology, the firm has relied on its newest technical employee and solar engineer John, who lives in Denver, Colorado. John was the lead engineer of the SkyLouver effort for a number of years before MBC purchased the technology in 2010. Steve and two team leaders traveled to Denver in 2010 to be trained on the assembly of SkyLouver. In developing the manufacturing process for SkyLouver, Robert and Steve relied on the following: (a) their new engineer (John) on the project, (b) their own limited knowledge of the SkyLouver product, (c) their experiences in various manufacturing environments, (d) suppliers' assistance with equipment and process techniques, and (e) their ability to search the internet for additional ideas.

SkyLouver module solar panel production is being performed on two upper floors in Building 8 that had been unused since the cessation of paint applicator production a number of years ago. MBC installed a $\$ 90,000$ elevator to handle movement of the large SkyLouver production equipment as well as the SkyLouver raw materials and finished components between floors. A sixth team was developed comprised of SkyLover technical, marketing and manufacturing interests.

\section{Quality Control}

Teams perform their own quality control; each employee reviewing work performed in the previous operation as well as their own. Each brush finish goods box is marked with the packer's name. The name of the production operator for each labor activity is recorded on the work order document. Each operator is responsible for the quality of products they produce. Through this documentation, any product complaints can be taken right to its manufactured source.

If raw materials used in brush manufacturing do not meet expected specifications, the matter is reviewed. After conferring with the supplier, the materials are returned to the supplier with a formal complaint according to MBC's ISO quality manual. To maintain supplier relations and increase employee understanding of the materials used in production, management occasionally takes production employees on visits of their suppliers' facilities.

The manufacturing engineer describes MBC's overall QC process as follows, "Well, here at Maryland Brush, everything that is made has a work process and checkpoints involved in that." These processes follow general guidelines of ISO 9001 standards. MBC became ISO certified because the process helps the company understand and comply with the needs of the customer and because customers were requiring that products and services 
conform to ISO practices according to Steve. The company's outside ISO registrar performs an annual audit of the operation, and employees perform self-audits annually as well. The audits, “... make sure we're within standards, and we're doing things the way we're supposed to be doing them. ... And the larger customers out there now demand that their suppliers are ISO."

The process developed for producing the solar energy modules is based on the same quality principles the firm already adheres to based on its ISO quality management system. As Robert noted, "Quality is a mindset that was already here. ... if you bring on a different product, as much different as SkyLouver is..., you still have the same quality mindset."

\section{Customer Service/Marketing}

MBC sells products all over the continental United States as well as internationally. Two of its larger foreign markets are Mexico and South Africa. Customer relations and traditional order entry activities are managed by MBC's Customer Support Team. Team members include Susan, Ruth, Don and Steve, all located in Baltimore, and Tim - located in New Jersey. The Customer Sales Team is made up of Tim, Jim who lives in Illinois, and Bill a new sales rep who joined MBC in 2012 to handle the SkyLouver sales and marketing effort. The team is supported by six sales representative firms, each covering a different geographic region. These sales firms are commission only and represent other non-brush product lines in their territories. Tim covers a geographic region and manages the sales reps through promotion, education, and solicitation of orders for the brush effort. Jim is the member of the sales team who focuses on a specific industry - steel and non-ferrous metal rolling mills for the brush effort. Tim indicated that sales personnel make essentially two types of calls: one type is at the distributor level usually with a sales rep, and the second is to end users who might be looking for help in designing a brush for a particular application. MBC has developed long term customers for its brushes over the years. According to Susan, the firm's customers "... are very dedicated". 'We have a great customer base. We're very close with a lot of our customers. We know their ordering habits and everybody's names ...."

MBC is similar to other industrial firms in the methods it uses to attract customers. The primary means is through its sales representatives. The firm also engages in cooperative advertising with distributors, having its products included in the distributors' catalogues and promotional literature. The firm also participates in multiple trade shows where it exhibits and demonstrates products and discusses its engineering services. The firm has two websites, www.marylandbrush.com and www.skylouversystems.com, allowing customers to learn about the company and its abilities, and to look up products and request a quote. The marketing staff feels that MBC has picked up business from the internet. The firm works to make it easy for the customer to buy product from them. Finally, the firm has joined buying groups where customers come together to increase their buying power from suppliers such as MBC.

SkyLouver marketing strategy is still being developed and implemented. It is a collection of efforts including displaying at trade shows and on the internet, targeting of building owners/operators within specific industries, contacting building and energy consultants, architects and service providers, and networking through available channels.

\section{Human Resource Practices}

In addition to the programs discussed under employee involvement, $\mathrm{MBC}$ employs other human resource management practices. MBC provides a generous compensation benefits package. Most of our employees have been hired by word of mouth. In the rare instance when an employee is laid-off, they often do not seek employment with another company, but would rather wait until recalled by MBC. According to Margie, she was laid-off in 2009 “...for 6 months and for a period in 2002. I always come back", she said. In accordance with the union contract, an MBC employee who is laid-off will maintain their seniority and benefits rights for up to one (1) year after layoff. Interviews to hire potential employees are conducted by a group of the employees in the particular job category to be hired. For example, if the position that is being filled is an hourly position, then a group of hourly workers will interview the candidate. After the wage group completes its interviews, it will make a selection for new hire which is reviewed by the President. 
A vacant salary position is filled in a similar manner with candidates being interviewed by a group of salaried employees. Once the salary group makes a final decision, it is reviewed by the President and the Board of Directors.

MBC offers its employees a number of other benefits. For example, the union workers also have a pension program partially paid for by MBC and partially paid for and administered by the union. As explained by Steve, "We have a traditional pension with our union group...We make a contribution every payroll. It's a small amount, and the Steelworkers fund most of it". MBC sponsors the pension plan for its union members, and a 401(k) plan for all employees. The $401(\mathrm{k})$ is a traditional program where employees invest pretax income into their accounts, and MBC matches the employee contribution up to a maximum of 6 percent. Employees are eligible to participate in the $401(\mathrm{k})$ program after only a 30 day waiting period. As with most $401(\mathrm{k})$ programs, the participation by the employee is voluntary, but as one employee stated, "The vast majority of employees participate in the program." Caring for its employees and recognizing its ESOP roots, MBC also provides a very generous medical insurance program with minimal employee premium share requirements.

\section{Recent Financial Performance}

MBC Ventures like many small, closely-held companies does not make its financial information public even though it practices open-book management internally. MBC has provided two graphs - one of sales and one of owners' equity - for the last six years (Exhibit III). As can be seen, overall sales decreased between 2006 and 2008. This decrease was due to MBC continuing to focus on the niches where it has a competitive advantage as addressed earlier. As can be seen also is the positive effect on owners' equity as the firm increased its mix of high profit margin engineered brushes and decreased its mix of low margin commodity-priced ones. Between 2008 and 2009, the "Great Recession" hit sales hard because MBC products are used primarily in industries that manufacture capital goods. Stockholders' equity also decreased between 2008 and 2009, but not as steeply due to steps taken by management to reduce costs. That decrease continued between 2009 and 2010 as sales began to turn around in 2010. In 2011, as sales rose back to almost prerecession levels, the strategy to focus on high margin engineered brushes paid off as stockholders' equity soared.
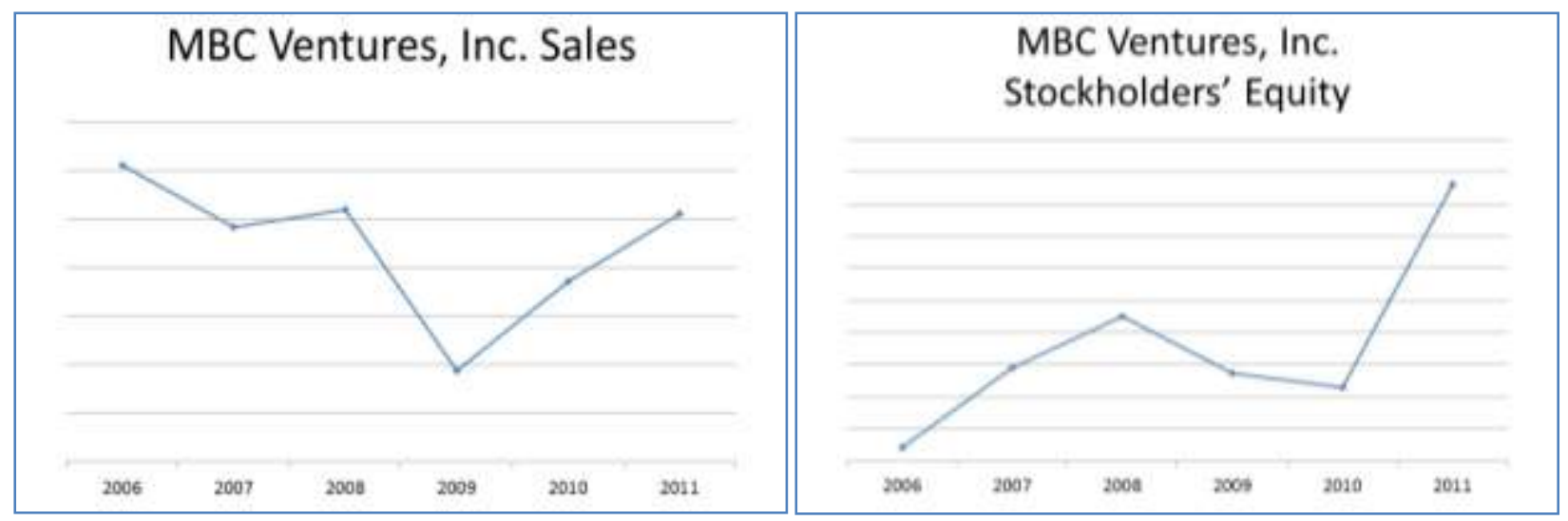

Exhibit III Financial Graphs

\section{ORGANIZATIONAL ATMOSPHERE AND A LOOK TO THE FUTURE}

In general, MBC employees at all levels appear to be satisfied working for the company. The long tenure of many employees, the low turnover, and the fact that employees are willing to suffer through layoffs in hopes of being recalled are indications of their commitment. The positive work environment at MBC appears to be due to a number of factors. The employees describe what they best like about working at MBC:

The first thing, ...It's a small company now, so I get to do a lot of different things. I'm always busy. Every day is new. So for me it's the work. The diversity of the work, and the fact that I can be involved in so many different things. [Secondly,] I would say that it is the flexible environment. ... The fact that you don't have a lot of supervision 
is good for self-directed people. ... [Thirdly,] I would say the fact that we are employee owned... I think I have a big influence .... (Ruth, Office Team Leader)

"For me it's a great place to work because... you don't have that supervision standing over the top of your shoulder. ... You are involved in some of the decision making on the floor where, before, with the supervisor, you were just told, 'You do this, ' and that's it." (Richard, Tool and Die Maker and local union President)

"Yeah, I get the feeling that this organization is one where you can go talk to whoever you need to talk to, and there's no standing on formality here. ... The communication from all levels is open." (Robert, Manufacturing Engineer)

"Our union and our management get along well. And Steve respects us as workers. And...we respect him. I mean if we have a problem, we address it with him, and he treats us like human beings, which is important. (Colleen, Team Leader)

"The fact that it is an ESOP. ...Everyone gets along wonderfully. The office personnel, there's not many of us, but we work very closely together. The fact that we are employee owners, ... we control a lot of our future. And I have no intention of going anywhere else." (Susan, Accounting)

"...The best thing, I'd say, is our co-workers. ... You have to work together as a team and that's basically what we do. If we have a problem or something like that, we pitch in and help out, everybody works together as a team." (Margie, Machine Operator)

It appears that the positive aspects of the work environment at MBC are due not only to formal management practices employed such as the ESOP, gainsharing, and team structure, but also due to its small size that facilitates communication and to the tone set by the President (Steve's) management style.

Despite its positive organizational environment, MBC faces some challenges over the next few years. In the short run, the firm will have to replace experienced employees in brush manufacturing who may decide to migrate to the new product group in SkyLouver once production picks up. There will be a number of retirements in the next few years; this will require recruitment of new employees who are bound to change the culture of the current work environment. Most importantly is the challenge posed by competing in a mature industry and the financial and emotional risk associated with the recent diversification effort of the SkyLouver alternative energy technology. In considering MBC's future, Steve pondered the challenge posed by the firm's new product line:

"It is hoped and expected that our solar business will be very successful and that it grows to be much larger than our brush business. If it does not grow to exceed our brush business, we will surely be disappointed. However, we will still be profitable and secure, and we will continue to provide good jobs to our employees and support our community."

\section{ACKNOWLEDGEMENTS}

The authors would like to thank the employee-owners of MBC Ventures who graciously shared their knowledge, experiences, and perspectives about the company. Their viewpoints are invaluable in ensuring that this case provides a true representation of the culture and practices of the company. The authors would like to also acknowledge that research on this company was partially supported by the Foundation for Enterprise Development and the National Center for Employee Ownership. The case is copyrighted by the authors.

\section{AUTHOR INFORMATION}

Richard C. Hoffman (Ph.D. Indiana) is a Professor of Management at in the Franklin P. Perdue School of Business at Salisbury University. His professional interests include strategic and international management and shared entrepreneurship. His research has appeared in: Decision Sciences, Journal of International Business Studies, Journal of Management, Long Range Planning, Management International Review, and Multinational Business 
Review, etc. as well as in casebooks. He has served as an interim dean and has held visiting appointments in China, Estonia, France, and Switzerland. He is a member of the Academy of International Business, Academy of Management and the Strategic Management Society. Richard C. Hoffman, Professor of Management, \& Fulbright Fellow, Franklin P. Perdue School of Business, Salisbury University, 1101 Camden Avenue, Salisbury, MD 21801. E-mail: rchoffman@salisbury.edu

M. O. "Mo" Brown, Jr. (J.D., University of Dayton, School of Law, M.B.A., the College of William \& Mary) is a Lecturer of Management at the Franklin P. Perdue School of Business at Salisbury University in Salisbury, Maryland. His current research interests include employment and labor law issues particularly as they relate to ESOP's (Employee Stock Ownership Plans). In addition to his teaching and research interests, Brown owns and operates a feeder cattle business in the Shenandoah Valley of Virginia. Marvin O. Brown, Lecturer of Management, Franklin P. Perdue School of Business, Salisbury University, 1101 Camden Avenue, Salisbury, MD 21801. E-mail: mobrown@salisbury.edu

Frank Shipper (Ph.D. Utah) is Professor of Management and Chair of Management and Marketing in the Franklin P. Perdue School of Business at Salisbury University. His current teaching, consulting, and research interests are managerial/leadership skills development, and employee ownership and culture. His articles have appeared in the Academy of Management Journal, Organizational Dynamics, Leadership Quarterly, Human Relations, Academy of Management Learning \& Education, and others. He has been recognized by the Academy of Management and the Center for Creative Leadership for his work on management development. As a consultant, he assists organizations in developing and validating their management development processes. Frank Shipper, Professor of Management, \& Louis O. Kelso Fellow, Franklin P. Perdue School of Business, Salisbury University, 1101 Camden Avenue, Salisbury, MD 21801. E-mail: fmshipper@salisbury.edu (Corresponding author)

\section{REFERENCES}

1. Atwood, L. (1990, February 12). Buyout keeps paint brush plant open. Baltimore Evening Sun, pp. F1, F12.

2. Logue, J., Glass, R., Teodosio, A., \& Cooper, C. (1998). Participatory Employee Ownership: How it Works. Ithaca, NY: Cornell University's Worker Ownership Institute.

3. Machinist. (n.d.). In Wikipedia. Retrieved June 18, 2013, from http://en.wikipedia.org/wiki/Machinist 


\section{APPENDIX A}

\section{Glossary}

Die setter - An individual who places the tool into a machine that can punch holes or cut different shapes into metal or other material.

Gainsharing - A system of management in which an organization seeks higher levels of performance through the involvement and participation of its people. The typical Gainsharing program measures performance and compares it with a historical standard. If the standard is exceeded, employees may earn a Gainsharing bonus generally on a monthly or quarterly basis. Gainsharing measures are typically based on operational measures (productivity, spending, quality, customer service) which are controllable by employees rather than organizationwide profits.

ISO - International Organization for Standardization establishes standards on a variety of subjects pertaining to business and government. ISO 9001 are standards for establishing quality management systems in organizations.

Machinist - A person who uses machine tools to make or modify parts, primarily metal parts, a process known as machining. This is accomplished by using machine tools to cut away excess material much as a woodcarver cuts away excess wood to produce his work. In addition to metal, the parts may be made of many other kinds of materials, such as plastic or wood products. The goal of these cutting operations is to produce a part that conforms to a set of specifications, or tolerances, usually in the form of engineering drawings commonly known as blueprints (Wikipedia, 2013).

Brush Making Machine - Custom designed and built production machine that evenly distributes metal or synthetic filaments around metal stampings and subsequently secures the filaments within those stampings, permitting additional operations to be performed on the subassembly. 


\section{APPENDIX B}

\section{Gainsharing Measures and Scoring}

The gainsharing system used at MBC reviews four broad areas of company performance on a monthly basis: productivity, quality, safety and financial. Each of these areas is assessed using one or two measures or standards with differential weights.

Measures - performance to standard assesses direct labor involved in production only, not office or warehousing work. Management compares the value of what is produced to the value of the labor it took to produce it. Because performance is reported monthly but the work is not evenly distributed by month, the firm uses a two month (current and prior month) weighted average for this measure. This carries the greatest weight in the matrix. Indirect labor or services and other non-direct manufacturing labor costs are taken into account here. In a similar fashion it is compared to the value of what has been produced and accounts for $10 \%$ of the model. The third measure used is the cost of materials used in production that month compared to standard; it is also weighted $10 \%$. Next are credit memos that are developed from customer complaints and returns, also worth $10 \%$ in the matrix. The next element or measure is safety days or lost time accident days. For example if today an employee is injured and leaves to get stitches today is not a safety day. But the next day if the person is still out then it is a safety day. On the financial performance side operating expense ratio takes all expenses (administrative and selling) except for direct and indirect labor and compares it to the value of what has been manufactured and it accounts for $10 \%$ of the score. Finally, operating income is $20 \%$ of the model. Operating versus net income is used because employees have more influence on the expenses associated with running the business and not the loans and tax decisions reflected in net income.

The actual performance numbers that appear in the matrix were developed from the company's own performance data over the years. The baseline represents the standard the company has consistently been able to meet.

Calculating GS Points - The data is reviewed every month and a gainshare score is calculated every month using the left hand column entitled "Monthly". Each quarter the three monthly scores are totaled, and the potential payout is calculated according to the formula below the matrix entitled "Pay out".

Perhaps an example is in order here: - Assume the following scores for each measure in the column below labeled "standard": Gainshare points are calculated by multiplying the score of the measure, which is the number from 0-10 listed in the column to the far right of the matrix itself in Exhibit II, by the weight for the measure listed in the row at the bottom of the matrix itself. Thus, for a performance to standard of 100, that yields a score of 10 multiplied by the weight of 35 or 350 points for this single element. Remaining scores and calculation appears in table below:

\begin{tabular}{|l|c|c|c|c|}
\hline \multicolumn{5}{|c|}{ Sample March Monthly Gainshare Points } \\
\hline \multicolumn{1}{|c|}{ Measure } & Standard & Score & Multiplied by Weight & GS Points \\
\hline Performance to standard & 101.4 & 10 & 35 & 350 \\
\hline Indirect labor & 1.30 & 10 & 10 & 100 \\
\hline Material utliz. & 4,250 & 0 & 10 & 0 \\
\hline Credit memos & 3 & 10 & 5 & 100 \\
\hline Safety days & 0 & 10 & 10 & 50 \\
\hline Operating Expense ratio & 4.28 & 0 & 20 & 0 \\
\hline Operating income & 29,500 & 0 & Total points for month & $\mathbf{6 0 0}$ \\
\hline
\end{tabular}


Determining the Payout

\begin{tabular}{|l|c|c|c|}
\hline \multicolumn{2}{|c|}{ Quarterly } & \multicolumn{2}{c|}{ Payout } \\
\hline \multicolumn{1}{|c|}{ Month } & Points & & 710 \\
\hline Jan & 480 & 1610 minus 900* & $\$ 71,000$ \\
\hline Feb & 530 & X's $\$ 100$ & $\$ 35,500$ \\
\hline March & 600 & X's .50 & $1183.33 /$ person max (based on hours worked) \\
\hline Total & 1610 & Divided by no. of Employees $=30$ & \\
\hline
\end{tabular}

The monthly points are simply totaled for the quarter. In the payout calculation, 900 points are deducted from the quarterly total because that represents the points earned if the firm simply made the baseline each quarter. The gainsharing program seeks to reward employees for exceeding baseline. Each person from the CEO to the shop floor can receive no more than the max amount. A person's share may be reduced due to absences (illness or unexcused); one is not penalized for paid vacation time. 


\section{NOTES}

